\title{
ERCCI mRNA levels and survival of advanced gastric cancer patients treated with a modified FOLFOX regimen
}

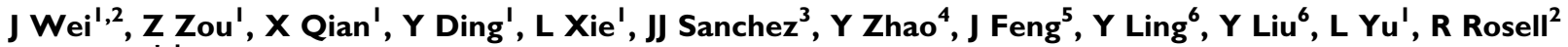 \\ and B Liu*,I
}

'Department of Oncology, Drum Tower Hospital, Clinical Cancer Institute of Nanjing University, Medical School of Nanjing University, Nanjing 210008 , China; ${ }^{2}$ Medical Oncology Service, Catalan Institute of Oncology, Hospital Germans Trias i Pujol, Badalona 08916, Spain; ${ }^{3}$ Department of Preventive Medicine and Public Health, Autonomous University of Madrid, Madrid 28029, Spain; ${ }^{4}$ Department of Epidemiology and Biostatistics and Data Analysis Center, School of Public Health, Nanjing Medical University, Nanjing 210019, China; ${ }^{5}$ Department of Oncology, Jiangsu Cancer Hospital, Nanjing 210009, China; ${ }^{6}$ Department of Oncology, Changzhou Cancer Hospital, Suzhou University, Changzhou 21300 I, China

Molecular markers involved in DNA repair can help to predict survival in gastric cancer patients treated with 5-FU plus platinum chemotherapy. Excision repair cross-complementing I (ERCCI) and thymidylate synthase (TS) mRNA expression levels were assessed in advanced gastric cancer tumour samples using real-time quantitative PCR in 76 patients treated with a modified FOLFOX (biweekly oxaliplatin plus 5-FU and folinic acid) regimen. Median survival time in patients with low ERCCI levels was significantly longer than in those with high levels (I 5.8 vs 6.2 months; $P<0.000$ I). Patients with high TS levels had longer survival than those with low levels (I2.2 vs 10.1 months; $P=0.01$ ). Forty-eight patients with low $E R C C I$ and high $T S$ levels had a median survival of I6.I months $(P<0.000 \mathrm{I})$. The hazard ratio for patients with high ERCCI expression was $9.4(P<0.000 \mathrm{I})$. In patients with high mRNA levels of $E R C C I$, alternative chemotherapy regimens should be considered.

British Journal of Cancer (2008) 98, I 398 - | 402. doi: I 0. I038/sj.bjc.66043I7 www.bjcancer.com

Published online 25 March 2008

(c) 2008 Cancer Research UK

Keywords: ERCCI; TS; advanced gastric cancer, FOLFOX

Gastric cancer currently ranks the third among most common cancers and will remain a significant cancer burden in China during the next decade. In 2005, there were approximately 400000 new cases and 300000 deaths from gastric cancer (Yang, 2006). There is currently no established standard regimen for advanced gastric cancer; however, biweekly oxaliplatin plus 5-fluorouracil (5-FU) and folinic acid (FOLFOX) was well tolerated and yielded median survival times of 9.6-11.4 months in five phase II studies (Louvet et al, 2002; Al-Batran et al, 2004; Chao et al, 2004; De Vita et al, 2005; Lordick et al, 2005). Considerable published evidence suggests that interindividual variation in response to 5-FU results from variations in the thymidylate synthase (TS) mRNA expression levels of the tumour (Longley et al, 2003). A sensitive quantitative polymerase chain reaction (QPCR) permits the detection of mRNA in small quantities that could not be detected by conventional methods used to detect proteins. TS mRNA levels in frozen endoscopic biopsies were inversely related to response and survival in 65 gastric cancer patients receiving neoadjuvant 5-FU plus cisplatin; median survival was 43 months for those with low TS levels and 6 months for those with high levels (Lenz et al, 1996). However, some tumours expressing relatively high levels of

*Correspondence: Dr B Liu;

E-mails: baoruiliu@nju.edu.cn and weijia01627@hotmail.com

Received 3 January 2008; revised 20 February 2008; accepted 26 February 2008; published online 25 March 2008
TS mRNA were surprisingly sensitive to 5-FU plus cisplatin (Lenz et al, 1996; Metzger et al, 1998). Intriguingly, it has recently been reported that gastric cancer cells that were rendered resistant to oxaliplatin exhibited significantly decreased TS levels, which resulted in enhanced susceptibility to 5-FU cytotoxicity. In addition, host cell reactivation assay revealed enhanced DNA repair of oxaliplatin damage in the resistant cells (Chen et al, 2007).

Cytotoxicity from cisplatin and other platinum-containing drugs, such as oxaliplatin, results from the formation of platinum DNA adducts (Schellens et al, 1996; van de Vaart et al, 2000). One determinant of the level of platinum DNA adducts in the tissue of patients treated with platinum-containing drugs is the rate of DNA repair. Individuals vary considerably in their capacity to remove DNA adducts, and tumour cell lines demonstrating in vitro resistance to cisplatin rapidly clear DNA adducts from the cells (Bosken et al, 2002). Nucleotide excision repair (NER) is the major pathway for repairing platinum-induced DNA damage. A series of proteins act to recognise base damage, unwind DNA, remove the damaged single-stranded fragment and synthesise a correct strand in its place (de Laat et al, 1999; Rosell et al, 2007). Excision repair cross-complementing 1 (ERCC1) is a key enzyme in the NER pathway. ERCC1 and TS mRNA levels were examined in 38 of the 65 gastric cancer patients (Lenz et al, 1996), for whom sufficient cDNA was available. Median survival for patients with low ERCC1 mRNA levels was not reached, while it was 5.4 months for those with high levels $(P=0.034)$. The differences in median survival 
according to TS mRNA levels were not significant (Metzger et al, 1998).

To further clarify the prognostic value of TS and ERCC1 mRNA expression, we examined by QPCR 76 formalin-fixed paraffinembedded tumour samples from FOLFOX-treated advanced gastric cancer patients and correlated the results with survival.

\section{PATIENTS AND METHODS}

\section{Patients}

Patients with histologically proven locally advanced or metastatic gastric cancer and Eastern Cooperative Oncology Group (ECOG) performance status (PS) $\leqslant 2$ were included in the study. All patients received a modified FOLFOX regimen chemotherapy after resection of primary tumours, as follows: oxaliplatin $85 \mathrm{mg} \mathrm{m}^{-2}$ on day 1 , plus folinic acid $200 \mathrm{mg} \mathrm{m}^{-2}$ as a $2 \mathrm{~h}$ infusion followed by bolus 5 -FU $300 \mathrm{mg} \mathrm{m}^{-2}$ and a $22 \mathrm{~h}$ infusion of 5 -FU $600 \mathrm{mg} \mathrm{m}^{-2}$ on days 1 and 2, every two weeks. Survival was calculated from the date of diagnosis to the date of last follow-up or death from any cause. All patients gave their signed informed consent, and the study was approved by the institutional ethics review boards.

\section{Total RNA extraction from formalin-fixed paraffin- embedded tissue}

Seven $7-\mu \mathrm{m}$ sections were prepared from primary tumour blocks that contained at least $80 \%$ tumour cells and directly transferred into a microcentrifuge tube. RNA was extracted according to a previously described method with minor modifications (Specht et al, 2001). Briefly, paraffin was removed by extracting three times with $1 \mathrm{ml}$ xylene for $10 \mathrm{~min}$ incubation at $50^{\circ} \mathrm{C}$ followed by rehydration through subsequent washes with 100,90 and $70 \%$ ethanol diluted in RNase-free water. The tissue was collected by centrifugation and resuspended in $200 \mu \mathrm{l}$ RNA lysis buffer containing $10 \mathrm{~mm}$ Tris-HCL, $0.1 \mathrm{~mm}$ EDTA, 2\% SDS and $500 \mu \mathrm{g} \mathrm{ml}^{-1}$ proteinase $\mathrm{K}$ and incubated at $60^{\circ} \mathrm{C}$ for $16 \mathrm{~h}$. RNA was purified by phenol and chloroform extractions followed by precipitation with isopropanol in the presence of sodium acetate and at $-20^{\circ} \mathrm{C}$. The RNA pellet was washed in $70 \%$ ethanol and resuspended in $20 \mu \mathrm{l}$ of RNase-free water.

\section{QPCR assessment of TS and ERCC1 expression}

cDNA was generated with a blend of random hexamers and oligodT 1:1 (ABgene, Surrey, UK) and the target cDNA sequences were amplified by quantitative PCR in a fluorescent temperature cycler (Mx 3000P Real Time PCR System, Stratagene). Briefly, total RNA $1 \mu \mathrm{g}$ was used for each $\mathrm{RT}$ reaction. The $20 \mu \mathrm{l}$ PCR reaction mixture contained $1 \times$ primers and probe mixture (Applied Biosystems, Foster city, CA, USA. Assay IDs: Hs00157415_m1 (ERCC1); Hs00426591_m1 (TS); Hs99999903_m1 ( $\beta$-actin)), $1 \times$ Absolute QPCR Mix (ABgene). The PCR conditions were $50^{\circ} \mathrm{C}$ for $2 \mathrm{~min}$, $95^{\circ} \mathrm{C}$ for $15 \mathrm{~min}$, followed by 45 cycles at $95^{\circ} \mathrm{C}$ for $15 \mathrm{~s}$ and $60^{\circ} \mathrm{C}$ for $1 \mathrm{~min}$. Relative gene expression quantifications were calculated according to the comparative $C_{\mathrm{t}}$ method using $\beta$-actin as an endogenous control and commercial human total RNA (BD Clontech, CA, USA) as calibrators. Final results were determined by the formula $2^{-\Delta \Delta C \mathrm{t}}$ (Livak and Schmittgen, 2001) and were analysed with the Stratagene analysis software.

\section{Statistical analysis}

The Mann - Whitney $U$-test was used to test significant association between gene expression levels and dichotomous variables. The Spearman's rho method was used to correlate expression levels of TS and ERCC1. The maximal $\chi^{2}$ method of Miller and Siegmund (Miller and Siegmund, 1982) and Halpern (Halpern, 1982) was adapted to determine which cutoff value best dichotomised patients into low- and high-expression TS and ERCC1 subgroups; the Tree method (LeBlanc and Crowley, 1992) was then applied to optimise these cutoff values. The final cutoff values were confirmed by recursive partitioning and amalgamation using S-Plus software, version 6.1 (Statistical Sciences, Seattle, WA, USA). Survival curves were obtained by the Kaplan-Meier method. Comparisons were made with the log-rank test and 1000 bootstrap-like simulations were performed to get the corrected $P$-values of the log-rank test. A univariate Cox model with overall survival as the dependent variable was constructed and categorised with gene expression levels as independent variables, and the genes that were significant in the univariate analysis were included in a multivariate Cox proportional hazards model for survival. All statistical analyses were carried out at a $5 \%$ level of significance and with a power of $80 \%$, using the Statistical Package for the Social Sciences, version 13 (SPSS Inc, Chicago, IL, USA).

\section{RESULTS}

\section{Patient characteristics}

A total of 76 gastric adenocarcinoma patients were included in the study. The median age was 57; 56 patients were male and the majority of patients had PS $0-1$. Twenty-one patients $(27.6 \%)$ had stage IIIA, $16(21.1 \%)$ had stage IIIB and 39 (51.3\%) had stage IV disease at the time of diagnosis. Patient characteristics are summarised in Table 1.

Table I Clinical factors associated with overall survival

\begin{tabular}{|c|c|c|c|c|}
\hline \multirow[b]{2}{*}{ Characteristics } & \multicolumn{2}{|c|}{ Patients } & \multirow{2}{*}{$\begin{array}{c}\text { MST } \\
\text { (Months) }\end{array}$} & \multirow{2}{*}{$\begin{array}{c}P \text { Log-rank } \\
\text { test }\end{array}$} \\
\hline & No. & Percentage & & \\
\hline \multicolumn{5}{|c|}{ Age, years (median: 57; range: $30-80$ ) } \\
\hline$<57$ & 36 & 47.4 & 15.7 & 0.943 \\
\hline$\geqslant 57$ & 40 & 52.6 & 10.7 & \\
\hline \multicolumn{5}{|l|}{ Sex } \\
\hline Male & 56 & 73.7 & 11.5 & 0.780 \\
\hline Female & 20 & 26.3 & 11.7 & \\
\hline \multicolumn{5}{|l|}{ ECOG PS } \\
\hline $0-1$ & 62 & 81.6 & 11.8 & 0.020 \\
\hline 2 & 14 & 18.4 & 8.1 & \\
\hline \multicolumn{5}{|l|}{ Initial staging } \\
\hline III & 37 & 48.7 & 19.2 & $<0.001$ \\
\hline IV & 39 & 51.3 & 9.6 & \\
\hline \multicolumn{5}{|l|}{ Grading } \\
\hline $\mathrm{G} 2^{\circ}$ & 20 & 26.3 & 10.7 & 0.972 \\
\hline G3 & 56 & 73.7 & 11.8 & \\
\hline \multicolumn{5}{|l|}{ Site of tumour } \\
\hline Proximal stomach & 28 & 36.8 & 9.8 & 0.45 \\
\hline Distal stomach & 42 & 55.3 & 12.2 & \\
\hline Whole stomach & 6 & 7.9 & 11.3 & \\
\hline \multicolumn{5}{|l|}{ No.of sites involved ${ }^{a}$} \\
\hline $0-1$ & 49 & 64.5 & 16.9 & 0.004 \\
\hline$\geqslant 2$ & 27 & 35.5 & 7.6 & \\
\hline
\end{tabular}

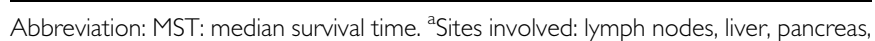
peritoneum, lung, pleura. 


\section{Gene expression levels}

ERCC1 and TS levels were detected in all tumours, with median gene expression relative to housekeeping $\beta$-actin for ERCC1 of 0.039 (range $0.001-5.23,95 \%$ confidence interval (CI): $0.26-0.83$ ) and for TS of 8.83 (range $0.72-78.79,95 \%$ CI: $8.03-12.34$ ). Using a cutoff value of $0.47,61$ patients $(80.3 \%)$ had low ERCC1 expression levels and $15(19.7 \%)$ patients had high levels. Using a cutoff value of $6.06,55(72.4 \%)$ patients had low TS expression levels and 21 $(27.6 \%)$ had high levels. There was no significant association between ERCC1 and TS levels $(\rho=-0.1, P=0.39)$. ERCC1 mRNA expression levels were lower in patients with PS 0-1 (median value: 0.017) than in those with PS 2 (median value: 0.099) $(P=0.03)$. Distal gastric cancer was present in $62.3 \%$ of patients with low ERCC1 levels and proximal gastric cancer was present in $53.3 \%$ of patients with high ERCC1 levels $(P=0.02)$. No significant association was detected between ERCC1 or TS mRNA expression and other clinical parameters.

\section{Survival}

Median survival time for all patients was 11.5 months (95\% CI: 8.4-14.6 months). A significant association was observed between survival and PS $(P=0.02)$, tumour stage $(P<0.001)$ and number of sites involved $(P=0.004)$. No other association between clinical characteristics and survival was found (Table 1).

A significant association was also observed between survival and gene expression levels. Median survival for patients with low ERCC1 expression levels was 15.8 months (95\% CI: 10.2-21.5 months) compared with 6.2 months (95\% CI: 4.6-7.9 months) for those with high levels $(P<0.0001)$ (Table 2, Figure 1). Median survival for patients with high TS expression levels was 12.2 months (95\% CI: $3.7-16.4$ months) compared to 10.1 months (95\% CI: 5.4 - 18.9 months) for those with high levels $(P=0.01)$ (Table 2).

Among the 55 patients with high TS expression levels, 48 patients with low ERCC1 levels had a median survival of 16.1 months (95\%CI: 7.8-24.4) compared to 6.9 months (95\% CI: $5.2-8.6)$ for the seven patients with high ERCC1 levels $(P<0.0001)$ (Figure 2A). Among the 21 patients with low TS expression levels, 13 patients with low ERCC1 levels had a median survival of 15.1 months (95\% CI: 9.2-21.1) compared to 5 months (95\% CI: $4-6.1$ ) for the 8 patients with high ERCC1 levels $(P=0.001)$ (Figure $2 \mathrm{~B}$ ).

The multivariate analysis identified ERCC1 mRNA expression levels (hazard ratio (HR), 9.4; $P<0.0001$ ) and number of sites involved $(\mathrm{HR}, 1.9 ; P=0.03)$ as independent markers for survival (Table 3).

\section{DISCUSSION}

In this first QPCR analysis of ERCC1 and TS mRNA expression in formalin-fixed paraffin-embedded tumour tissue in advanced gastric cancer, we have found that ERCC1 - but not TS - mRNA expression is associated with survival in patients receiving a

Table 2 ERCCI and TS mRNA expression and survival in advanced gastric cancer patients

\begin{tabular}{lccc}
\hline Factors & No. of patients & MST (Months) $\mathbf{( 9 5 \%} \mathbf{C l})$ & $\mathbf{P}^{\mathbf{a}}$ \\
\hline ERCCI mRNA & & & \\
Low $\leqslant 0.47$ & 61 & $15.8(10.2-21.5)$ & $<0.000$ । \\
High $>0.47$ & 15 & $6.2(4.6-7.9)$ & \\
& & & \\
TS mRNA & 21 & $10.1(5.4-18.9)$ & 0.01 \\
Low $\leqslant 6.06$ & 55 & $12.2(3.7-16.4)$ & \\
High $>6.06$ & 5
\end{tabular}

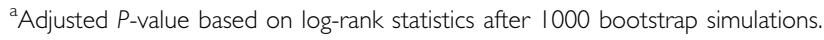

modified FOLFOX regimen. These findings are along the same lines as the seminal study by Metzger et al (1998) where ERCC1 and TS mRNA levels were quantified in frozen tumour tissue from gastric cancer patients receiving 5-FU plus cisplatin. Since the time of writing the present report, another study in paraffin-embedded tumour tissue has confirmed the role of ERCC1 mRNA expression in a heterogeneous cohort of gastric cancer patients - 69 treated

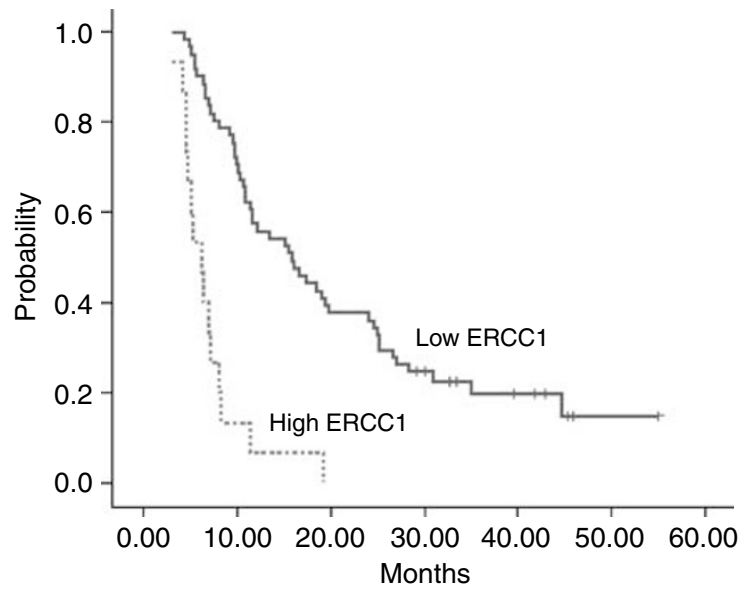

Figure I Kaplan-Meier estimates of overall survival by ERCCI mRNA expression levels ( $N=76$; low ERCCI: 61; high ERCCI: I5).
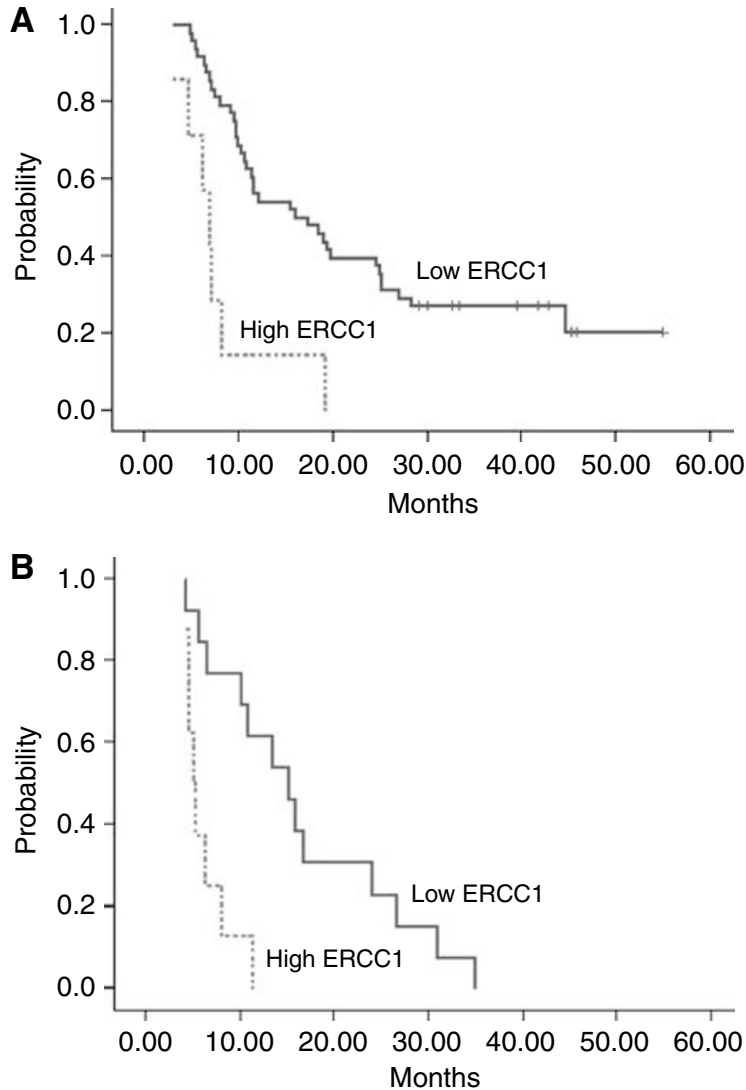

Figure 2 Kaplan-Meier estimates of overall survival according to ERCCI mRNA expression in patients with high TS mRNA expression $(\mathbf{A})(N=55$; high TS and low ERCCI: 48; high TS and high ERCCI: 7) and in patients with low TS expression (B) $(N=21$; low TS and low ERCCI: I3; low TS and high $E R C(1: 8)$. 
Table 3 Multivariate analysis of factors associated with overall survival

\begin{tabular}{|c|c|c|c|}
\hline Factors & No. of patients & $\begin{array}{c}\text { Hazard Ratio } \\
(95 \% \mathrm{CI})\end{array}$ & $P$ \\
\hline \multicolumn{4}{|l|}{ ERCCI mRNA } \\
\hline Low $\leqslant 0.47$ & 61 & I (ref.) & \\
\hline High > 0.47 & 15 & $9.4(4.1-21.7)$ & $<0.0001$ \\
\hline \multicolumn{4}{|l|}{ Initial staging } \\
\hline III & 37 & I (ref.) & \\
\hline IV & 39 & $1.6(0.9-2.9)$ & 0.08 \\
\hline \multicolumn{4}{|l|}{ ECOG PS } \\
\hline $0-1$ & 62 & I (ref.) & \\
\hline 2 & 14 & $1.8(0.9-3.3)$ & 0.07 \\
\hline \multicolumn{4}{|l|}{ No.of sites involved } \\
\hline $0-1$ & 49 & I (ref.) & \\
\hline$\geqslant 2$ & 27 & $1.9(1.1-3.3)$ & 0.03 \\
\hline \multicolumn{4}{|l|}{ Site of tumour } \\
\hline Whole stomach & 6 & I (ref.) & \\
\hline Proximal stomach & 28 & $4.4(1.3-14.5)$ & 0.02 \\
\hline Distal stomach & 42 & $3.8(1.1-16.6)$ & 0.04 \\
\hline
\end{tabular}

with S-1, 23 with 5-FU and 43 with cisplatin plus either irinotecan or S-1. In the multivariate analysis of all 140 patients, ERCC1 emerged as an independent prognostic marker of survival (HR, 2.4; $P<0.001$ ); however, TS mRNA expression was not significant (HR, 0.3) (Matsubara et al, 2008). A study assessing ERCC1 and TS by immunostaining in 64 advanced gastric cancer patients treated with FOLFOX also showed significant differences according to ERCC1 expression. Median survival for patients with negative ERCC1 was 12.8 months, while it was 8.4 months for those with positive ERCC1 $(P=0.03)$. The multivariate analysis revealed a significant impact of ERCC1 expression on survival (HR, 1.9; $P=0.04$ ) (Kwon et al, 2007). However, TS expression was not found to be related to response or survival (Kwon et al, 2007), which concurred with the findings of a previous study (Choi et al, 2001). However, in the present study, using QPCR, the differences are much more striking ( 15.8 vs 6.2 months; $P<0.0001)$, with a HR of 9.4. The determination of relative gene expression through QPCR is currently considered to be a more sensitive and more quantitative methodology than immunostaining. Several studies have found no correlation between mRNA and protein levels of ERCC1 (Britten et al, 2000; Niedernhofer et al, 2007). When ERCC1 expression at the mRNA and protein levels was assessed by northern and western blotting, respectively, in a panel of cervical carcinoma cell lines, there was a significant correlation between ERCC1 mRNA - but not ERCC1 protein - levels and cisplatin resistance (Britten et al, 2000). In stage IV, non-small-cell lung cancer patients treated with cisplatin-based chemotherapy, ERCC1 protein expression did not predict response (Wachters et al, 2005), whereas ERCC1 mRNA expression was significantly associated with response (Cobo et al, 2007). Previous studies have tested ERCC1 mRNA expression in paraffin-embedded tumour samples in advanced colorectal cancer patients treated with 5-FU plus oxaliplatin (Shirota et al, 2001) and in non-small-cell lung cancer patients treated with gemcitabine plus cisplatin (Lord et al, 2002); both studies found a significant association between ERCC1 expression and survival. Cisplatin resistance is multifactorial, also involving the copper transporter ATP7A (Chen et al, 2007) and a 45-gene expression signature was a predictor of cisplatin sensitivity with $83 \%$ accuracy (Hsu et al, 2007). Interestingly, this gene signature includes ERCC1 and other DNA repair genes.

It is not clear, either in the Metzger study (Metzger et al, 1998) or in the present one, whether ERCC1 is a prognostic or a predictive marker. Interestingly, in the present study, ERCC1 mRNA levels were lower in patients with good PS, which has also been found in non-small-cell lung cancer patients (Cobo et al, 2007).

The role of $T S$ in predicting chemosensitivity remains controversial (Choi et al, 2001; Kwon et al, 2007; Matsubara et al, 2008). Although a meta-analysis reported that colorectal cancer patients with higher TS levels had poorer overall survival than those with lower levels (Popat et al, 2004), this predictive value was not confirmed in a prospective study (Smorenburg et al, 2006). In the present study, patients with higher TS levels had longer survival than those with lower levels, especially in patients with lower ERCC1 levels. Low levels of TS have been observed in oxaliplatin-resistant gastric cancer cell lines (Chen et al, 2007), providing a plausible potential explanation of why a meaningful number of patients with low ERCC1 and high TS levels had the longest survival in the present study (Figure 2).

Irinotecan and taxane-based regimens have been used in the treatment of advanced gastric cancer patients, with survival times similar to those attained with FOLFOX (Moehler et al, 2005; Oh et al, 2007; Takayama et al, 2007). However, the short survival attained in FOLFOX-treated patients with positive protein ERCC1 (HR, 1.91) (Kwon et al, 2007) or overexpression of ERCC1 mRNA (HR, 9.4) suggests that irinotecan or taxane-based regimens could be the better alternative for these patients. A randomised customised trial is warranted in this setting.

\section{ACKNOWLEDGEMENTS}

This paper was presented in part at the 43rd Annual Meeting of the American Society of Clinical Oncology, Chicago, Illinois, June 2007. We thank Dr Miquel Taron for his critical reading of the manuscript and helpful suggestions. The research was supported in part by the Research of Health Department in Jiangsu Province (H200640), the Medical Technology Development Foundation of Nanjing (ZKX05015) and the Clinical Medical Center for Hepatobiliary Disease in Jiangsu Province, China.

\section{REFERENCES}

Al-Batran SE, Atmaca A, Hegewisch-Becker S, Jaeger D, Hahnfeld S, Rummel MJ, Seipelt G, Rost A, Orth J, Knuth A, Jaeger E (2004) Phase II trial of biweekly infusional fluorouracil, folinic acid, and oxaliplatin in patients with advanced gastric cancer. J Clin Oncol 22: 658-663

Bosken CH, Wei Q, Amos CI, Spitz MR (2002) An analysis of DNA repair as a determinant of survival in patients with non-small-cell lung cancer. J Natl Cancer Inst 94: 1091 - 1099

Britten RA, Liu D, Tessier A, Hutchison MJ, Murray D (2000) ERCC1 expression as a molecular marker of cisplatin resistance in human cervical tumor cells. Int J Cancer 89: 453-457

Chao Y, Yeh KH, Chang CJ, Chen LT, Chao TY, Wu MF, Chang CS, Chang JY, Chung CY, Kao WY, Hsieh RK, Cheng AL (2004) Phase II study of weekly oxaliplatin and 24-h infusion of high-dose 5-fluorouracil and folinic acid in the treatment of advanced gastric cancer. Br J Cancer 91: $453-458$

Chen CC, Chen LT, Tsou TC, Pan WY, Kuo CC, Liu JF, Yeh SC, Tsai FY, Hsieh HP, Chang JY (2007) Combined modalities of resistance in an oxaliplatin-resistant human gastric cancer cell line with enhanced sensitivity to 5-fluorouracil. $\mathrm{Br} J$ Cancer 97: $334-344$ 
Choi J, Lim H, Nam DK, Kim HS, Cho DY, Yi JW, Kim HC, Cho YK, Kim MW, Joo HJ, Lee KB, Kim KB (2001) Expression of thymidylate synthase in gastric cancer patients treated with 5-fluorouracil and doxorubicin-based adjuvant chemotherapy after curative resection. $\mathrm{Br} J$ Cancer 84: $186-192$

Cobo M, Isla D, Massuti B, Montes A, Sanchez JM, Provencio M, Vinolas N, Paz-Ares L, Lopez-Vivanco G, Munoz MA, Felip E, Alberola V, Camps C, Domine M, Sanchez JJ, Sanchez-Ronco M, Danenberg K, Taron M, Gandara D, Rosell R (2007) Customizing cisplatin based on quantitative excision repair cross-complementing 1 mRNA expression: a phase III trial in non-small-cell lung cancer. J Clin Oncol 25: 2747-2754

de Laat WL, Jaspers NG, Hoeijmakers JH (1999) Molecular mechanism of nucleotide excision repair. Genes Dev 13: 768-785

De Vita F, Orditura M, Matano E, Bianco R, Carlomagno C, Infusino S, Damiano V, Simeone E, Diadema MR, Lieto E, Castellano P, Pepe S, De Placido S, Galizia G, Di Martino N, Ciardiello F, Catalano G, Bianco AR (2005) A phase II study of biweekly oxaliplatin plus infusional 5-fluorouracil and folinic acid (FOLFOX-4) as first-line treatment of advanced gastric cancer patients. Br J Cancer 92: $1644-1649$

Halpern J (1982) Maximally selected chi-square statistics for small samples. Biometrics 38: $1017-1023$

Hsu DS, Balakumaran BS, Acharya CR, Vlahovic V, Walters KS, Garman K, Anders C, Riedel RF, Lancaster J, Harpole D, Dressman HK, Nevins JR, Febbo PG, Potti A (2007) Pharmacogenomic strategies provide a rational approach to the treatment of cisplatin-resistant patients with advanced cancer. J Clin Oncol 25: 4350-4357

Kwon HC, Roh MS, Oh SY, Kim SH, Kim MC, Kim JS, Kim HJ (2007) Prognostic value of expression of ERCC1, thymidylate synthase, and glutathione S-transferase P1 for 5-fluorouracil/oxaliplatin chemotherapy in advanced gastric cancer. Ann Oncol 18: 504-509

LeBlanc M, Crowley J (1992) Relative risk trees for censored survival data. Biometrics 48: $411-425$

Lenz HJ, Leichman CG, Danenberg KD, Danenberg PV, Groshen S, Cohen H, Laine L, Crookes P, Silberman H, Baranda J, Garcia Y, Li J, Leichman L (1996) Thymidylate synthase mRNA level in adenocarcinoma of the stomach: a predictor for primary tumor response and overall survival. J Clin Oncol 14: 176-182

Livak KJ, Schmittgen TD (2001) Analysis of relative gene expression data using real-time quantitative PCR and the 2(-Delta Delta C(T)) method. Methods 25: 402-408

Longley DB, Harkin DP, Johnston PG (2003) 5-fluorouracil: mechanisms of action and clinical strategies. Nat Rev Cancer 3: 330-338

Lord RV, Brabender J, Gandara D, Alberola V, Camps C, Domine M, Cardenal F, Sanchez JM, Gumerlock PH, Taron M, Sanchez JJ, Danenberg KD, Danenberg PV, Rosell R (2002) Low ERCC1 expression correlates with prolonged survival after cisplatin plus gemcitabine chemotherapy in non-small cell lung cancer. Clin Cancer Res 8: 2286-2291

Lordick F, Lorenzen S, Stollfuss J, Vehling-Kaiser U, Kullmann F, Hentrich M, Zumschlinge R, Dietzfelbinger H, Thoedtmann J, Hennig M, Seroneit T, Bredenkamp R, Duyster J, Peschel C (2005) Phase II study of weekly oxaliplatin plus infusional fluorouracil and folinic acid (FUFOX regimen) as first-line treatment in metastatic gastric cancer. Br J Cancer 93: 190 - 194

Louvet C, Andre T, Tigaud JM, Gamelin E, Douillard JY, Brunet R, Francois E, Jacob JH, Levoir D, Taamma A, Rougier P, Cvitkovic E, de Gramont A (2002) Phase II study of oxaliplatin, fluorouracil, and folinic acid in locally advanced or metastatic gastric cancer patients. J Clin Oncol 20: $4543-4548$

Matsubara J, Nishina T, Yamada Y, Moriwaki T, Shimoda T, Kajiwara T, Nakajima TE, Kato K, Hamaguchi T, Shimada Y, Okayama Y, Oka T, Shirao K (2008) Impacts of excision repair cross-complementing gene 1 (ERCC1), dihydropyrimidine dehydrogenase, and epidermal growth factor receptor on the outcomes of patients with advanced gastric cancer. Br J Cancer 98: 832-839

Metzger R, Leichman CG, Danenberg KD, Danenberg PV, Lenz HJ, Hayashi K, Groshen S, Salonga D, Cohen H, Laine L, Crookes P, Silberman H, Baranda J, Konda B, Leichman L (1998) ERCC1 mRNA levels complement thymidylate synthase mRNA levels in predicting response and survival for gastric cancer patients receiving combination cisplatin and fluorouracil chemotherapy. J Clin Oncol 16: 309-316

Miller R, Siegmund D (1982) Maximally selected chi-square statistics. Biometrics 38: $1011-1016$

Moehler M, Eimermacher A, Siebler J, Hohler T, Wein A, Menges M, Flieger D, Junginger T, Geer T, Gracien E, Galle PR, Heike M (2005) Randomised phase II evaluation of irinotecan plus high-dose 5 -fluorouracil and leucovorin (ILF) vs 5-fluorouracil, leucovorin, and etoposide (ELF) in untreated metastatic gastric cancer. Br J Cancer 92: $2122-2128$

Niedernhofer LJ, Bhagwat N, Wood RD (2007) ERCC1 and non-small-cell lung cancer. $N$ Engl J Med 356: 2538 - 2540; author reply 2540-1

Oh SC, Sur HY, Sung HJ, Choi IK, Park SS, Seo JH, Jeen YT, Chun HJ, Shin SW, Mok YJ, Kim JS, Kim YH (2007) A phase II study of biweekly doseintensified oral capecitabine plus irinotecan (bXELIRI) for patients with advanced or metastatic gastric cancer. Br J Cancer 96: 1514-1519

Popat S, Matakidou A, Houlston RS (2004) Thymidylate synthase expression and prognosis in colorectal cancer: a systematic review and meta-analysis. J Clin Oncol 22: 529-536

Rosell R, Mendez P, Isla D, Taron M (2007) Platinum resistance related to a functional NER pathway. $J$ Thorac Oncol 2(12): 1063-1066

Schellens JH, Ma J, Planting AS, van der Burg ME, van Meerten E, de Boer-Dennert M, Schmitz PI, Stoter G, Verweij J (1996) Relationship between the exposure to cisplatin, DNA-adduct formation in leucocytes and tumour response in patients with solid tumours. $\mathrm{Br} J$ Cancer 73 : $1569-1575$

Shirota Y, Stoehlmacher J, Brabender J, Xiong YP, Uetake $\mathrm{H}$, Danenberg KD, Groshen S, Tsao-Wei DD, Danenberg PV, Lenz HJ (2001) ERCC1 and thymidylate synthase mRNA levels predict survival for colorectal cancer patients receiving combination oxaliplatin and fluorouracil chemotherapy. J Clin Oncol 19: 4298-4304

Smorenburg CH, Peters GJ, van Groeningen CJ, Noordhuis P, Smid K, van Riel AM, Dercksen W, Pinedo HM, Giaccone G (2006) Phase II study of tailored chemotherapy for advanced colorectal cancer with either 5 -fluouracil and leucovorin or oxaliplatin and irinotecan based on the expression of thymidylate synthase and dihydropyrimidine dehydrogenase. Ann Oncol 17: 35-42

Specht K, Richter T, Muller U, Walch A, Werner M, Hofler H (2001) Quantitative gene expression analysis in microdissected archival formalin-fixed and paraffin-embedded tumor tissue. Am J Pathol 158: $419-429$

Takayama T, Sato Y, Sagawa T, Okamoto T, Nagashima H, Takahashi Y, Ohnuma H, Kuroiwa G, Miyanishi K, Takimoto R, Matsunaga T, Kato J, Yamaguchi K, Hirata K, Niitsu Y (2007) Phase I study of S-1, docetaxel and cisplatin combination chemotherapy in patients with unresectable metastatic gastric cancer. Br J Cancer 97: 851-856

van de Vaart PJ, Belderbos J, de Jong D, Sneeuw KC, Majoor D, Bartelink H, Begg AC (2000) DNA-adduct levels as a predictor of outcome for NSCLC patients receiving daily cisplatin and radiotherapy. Int J Cancer 89: $160-166$

Wachters FM, Wong LS, Timens W, Kampinga HH, Groen HJ (2005) ERCC1, hRad51, and BRCA1 protein expression in relation to tumour response and survival of stage III/IV NSCLC patients treated with chemotherapy. Lung Cancer 50: 211-219

Yang L (2006) Incidence and mortality of gastric cancer in China. World J Gastroenterol 12: 17-20 